\title{
Article \\ Antibacterial Activity and Amphidinol Profiling of the Marine Dinoflagellate Amphidinium carterae (Subclade III)
}

\author{
Maria Elena Barone ${ }^{1,+}{ }^{\oplus}$, Elliot Murphy ${ }^{2,+}$, Rachel Parkes ${ }^{1}$, Gerard T. A. Fleming ${ }^{3}$, Floriana Campanile ${ }^{4}(\mathbb{D}$, \\ Olivier P. Thomas $2, *, \mp\left(\mathbb{D}\right.$ and Nicolas Touzet ${ }^{1, *, \neq}$ \\ 1 Centre for Environmental Research, Sustainability and Innovation, Department of Environmental Science, \\ School of Science, Institute of Technology Sligo, Ash Ln, Ballytivnan, F91 YW50 Sligo, Ireland; \\ MariaElena.Barone@mail.itsligo.ie (M.E.B.); Rachel.Parkes@mail.itsligo.ie (R.P.) \\ 2 Marine Biodiversity, School of Chemistry, Ryan Institute, National University of Ireland Galway (NUI Galway), \\ University Road, H91 TK33 Galway, Ireland; E.MURPHY53@nuigalway.ie \\ 3 Discipline of Microbiology, School of Natural Science, National University of Ireland Galway (NUI Galway), \\ University Road, H91 TK33 Galway, Ireland; ger.fleming@nuigalway.ie \\ 4 Medical Molecular Microbiology and Antibiotic Resistance Laboratory (MMARLab), Department of \\ Biomedical and Biotechnological Sciences, University of Catania, Via Santa Sofia n. 97, 95123 Catania, Italy; \\ F.campanile@unict.it \\ * Correspondence: olivier.thomas@nuigalway.ie (O.P.T.); touzet.nicolas@itsligo.ie (N.T.) \\ + These first authors contributed equally to this work. \\ $\ddagger \quad$ These last authors contributed equally to this work.
}

\section{check for} updates

Citation: Barone, M.E.; Murphy, E.; Parkes, R.; Fleming, G.T.A.; Campanile, F.; Thomas, O.P.; Touzet, N. Antibacterial Activity and Amphidinol Profiling of the Marine Dinoflagellate Amphidinium carterae (Subclade III). Int. J. Mol. Sci. 2021, 22, 12196. https://doi.org/10.3390/ijms 222212196

Academic Editors: Sotiris K. Hadjikakou and Claudiu T. Supuran

Received: 13 October 2021

Accepted: 5 November 2021

Published: 11 November 2021

Publisher's Note: MDPI stays neutral with regard to jurisdictional claims in published maps and institutional affiliations.

Copyright: (c) 2021 by the authors. Licensee MDPI, Basel, Switzerland. This article is an open access article distributed under the terms and conditions of the Creative Commons Attribution (CC BY) license (https:// creativecommons.org/licenses/by/ $4.0 /)$.

\begin{abstract}
Microalgae have received growing interest for their capacity to produce bioactive metabolites. This study aimed at characterising the antimicrobial potential of the marine dinoflagellate Amphidinium carterae strain LACW11, isolated from the west of Ireland. Amphidinolides have been identified as cytotoxic polyoxygenated polyketides produced by several Amphidinium species. Phylogenetic inference assigned our strain to Amphidinium carterae subclade III, along with isolates interspersed in different geographic regions. A two-stage extraction and fractionation process of the biomass was carried out. Extracts obtained after stage- 1 were tested for bioactivity against bacterial ATCC strains of Staphylococcus aureus, Enterococcus faecalis, Escherichia coli and Pseudomonas aeruginosa. The stage- 2 solid phase extraction provided 16 fractions, which were tested against $S$. aureus and E. faecalis. Fractions I, J and K yielded minimum inhibitory concentrations between $16 \mu \mathrm{g} / \mathrm{mL}$ and $256 \mu \mathrm{g} / \mathrm{mL}$ for both Gram-positive. A targeted metabolomic approach using UHPLC-HRMS/MS analysis applied on fractions $\mathrm{G}$ to J evidenced the presence of amphidinol type compounds AM-A, AM-B, AM-22 and a new derivative dehydroAM-A, with characteristic masses of $m / z 1361,1463,1667$ and 1343, respectively. Combining the results of the biological assays with the targeted metabolomic approach, we could conclude that AM-A and the new derivative dehydroAM-A are responsible for the detected antimicrobial bioactivity.
\end{abstract}

Keywords: microalgae; Amphidinium carterae; antimicrobial activity; marine natural products (MNP); minimum inhibitory concentration (MIC); minimum bactericidal concentration (MBC); amphidinols; UHPLC-HRMS; targeted metabolomics

\section{Introduction}

The emergence of antimicrobial resistance has hindered the effectiveness of treatments for a growing number of bacterial infections worldwide [1,2]. The overuse and misuse of antibiotic drugs have led bacteria to develop adaptations to overcome the mechanisms of action of several commonly used drugs [3,4], hence requiring the urgent identification of novel antimicrobial compounds. Several bioactive metabolites isolated from marine bioresources, also known as marine natural products (MNPs), have elicited potent bioactivity against cancer and other ailments induced by pathogens such as viruses, bacteria and fungi [5-7]. Antimicrobial MNPs show a high chemical diversity and include, for example, 
alkaloids, terpenoids, peptides, halogenated compounds, polyketides, isocoumarins, or nucleosides [6,8].

Microalgae are photosynthetic organisms increasingly exploited in the context of bioenergy, bioremediation or the biorefinery of high-value compounds [9]. Some species can biosynthesise and accumulate compounds such as polysaccharides, pigments, proteins, vitamins, polyunsaturated fatty acids, antioxidants, and other bioactive molecules $[9,10]$. Microalgae have also been increasingly screened for new antibacterial drugs [6,11-16]. Compounds such as cyanovirin, oleic acid, linoleic acid, palmitoleic acid, $\beta$-carotene, fucoxanthin or phycocyanin do exhibit antioxidant or anti-inflammatory properties as well as antimicrobial activity, for example, against Staphylococcus aureus and MethicillinResistant Staphylococcus aureus (MRSA) [14,17-19].

Several marine dinoflagellates are known producers of potent bioactive compounds and some of them are biosynthesise biotoxins that can render shellfish unsafe for human consumption [20], including polyketides, ladder-shape polyethers, spirolides or alkaloids [21,22]. Polyhydroxylated polyketides, named amphidinols, have been identified in species of the marine dinoflagellate genus Amphidinium and have previously shown anti-fungal, anti-tumour and anti-bacterial activity [13,23-28]. In this context, this study aimed at assessing the antibacterial potential of a strain of the dinoflagellate Amphidinium carterae isolated from the west of Ireland. The fractions obtained sequentially using solvents of varying polarity in solid phase extraction were tested against several bacterial pathogens. Due to the low amount of material available, the main amphidinols present in the bioactive fractions were targeted and identified by a targeted metabolomic analysis using UHPLC-HRMS/MS.

\section{Results}

\subsection{Phylogenetic Characterisation of Strain A. carterae LACW11}

Sequencing of the D1D2 domain of the LSU rRNA gene and subsequent BLAST analysis indicated strain LACW11 to belong to the species Amphidinium carterae. The phylogenetic tree showed this strain to group with other members of the species in a sister clade to that including A. trulla, A. gibbosum, A. massarti, A. tomasi, A theodori and A. thermaeum (Figure 1). The four subgroups of Amphidinium carterae characterised in previous studies were visible; the Irish strain LACW11 clustering with other isolates from Europe, Canada, Brazil, Puerto Rico and Australia within subclade III.

\subsection{Amphidinium carterae Culture}

The culture of $A$. carterae LACW11 was maintained for 30 days in $\mathrm{f} / 2$ medium and harvested during the exponential phase (Figure 2). The recovered freeze-dried biomass was estimated at $850 \mathrm{mg}$ for $6.1 \mathrm{~L}$ of culture.

\subsection{Stage-1: Bioactivity Assays on the Extracts}

The freeze-dried biomass of Amphidinium carterae LACW11 was first extracted with $\mathrm{Et}_{2} \mathrm{O}$ then $\mathrm{MeOH}$. The methanol extract was then partitioned between EtOAc and $\mathrm{H}_{2} \mathrm{O}$ to provide three final extracts $\mathrm{E}_{\mathrm{Et} 2 \mathrm{O}}, \mathrm{E}_{\mathrm{EtOAc}}$ and $\mathrm{E}_{\mathrm{H} 2 \mathrm{O}}$. These extracts were tested for antimicrobial activity (Figure 3). 


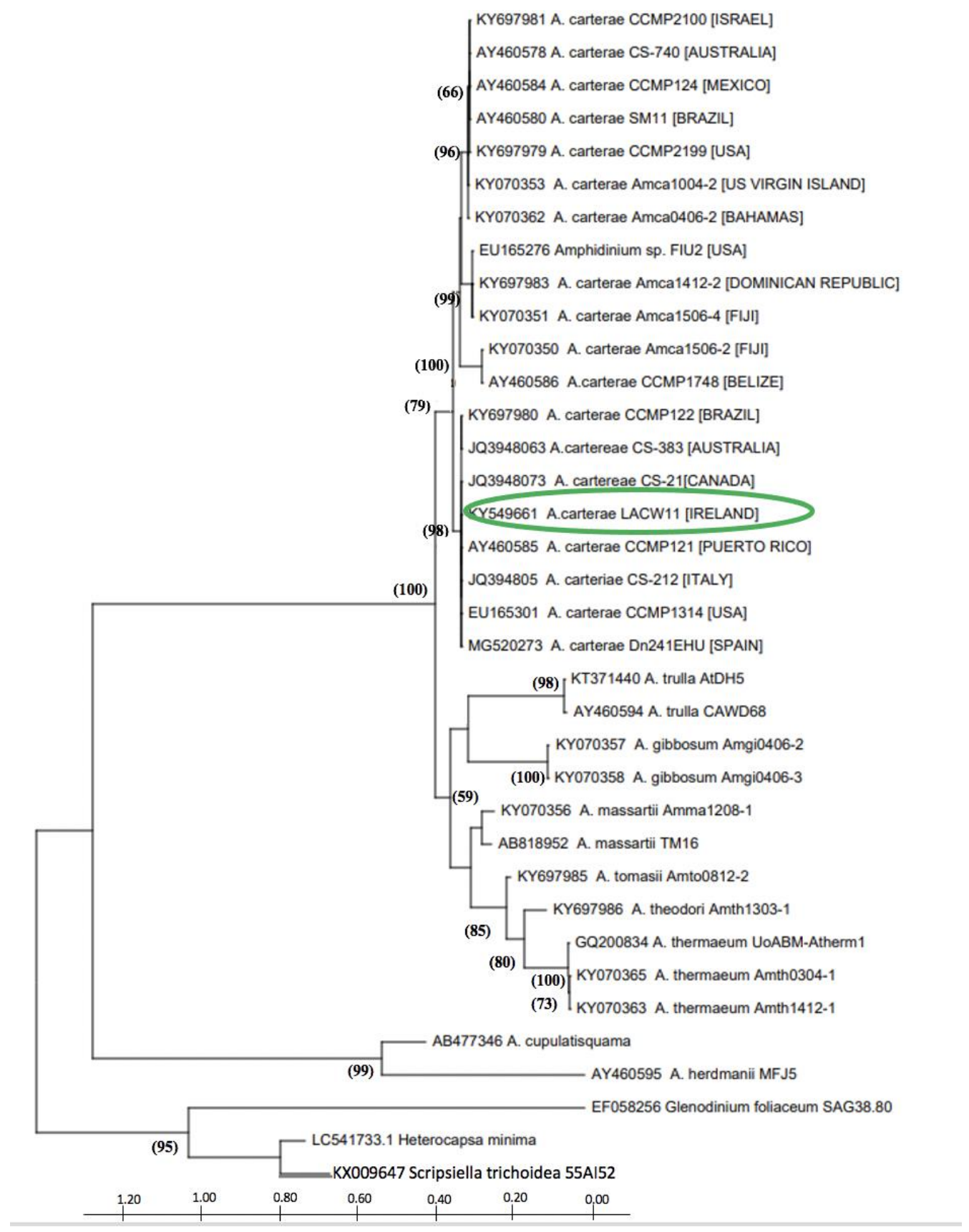

Figure 1. Phylogenetic tree inferred from the maximum likelihood analysis of partial LSU rDNA sequences of Amphidinium species. The optimal base substitution model derived from the Bayesian Information Criterion (BIC) using MEGA X was Tamure Nei gamma distributed (TN93 + G, parameter $=0.4032)$. Bootstrap values $(\%)$ of 1000 replicates are shown (only values $>50)$. The position of strain LACW42 in the tree is highlighted in green.

The assays for stage- 1 samples showed moderate antimicrobial bioactivity for extracts $\mathrm{E}_{\mathrm{Et} 2 \mathrm{O}}$ and $\mathrm{E}_{\mathrm{EtOAc}}$ against Staphylococcus aureus and Enterococcus faecalis, and low activities for the $\mathrm{E}_{\mathrm{H} 2 \mathrm{O}}$ extract. For $\mathrm{E}_{\mathrm{EtOAc}}$, the MIC values against $S$. aureus and E. faecalis were 256 and $512 \mu \mathrm{g} / \mathrm{mL}$, respectively. Only $\mathrm{E}_{\mathrm{EtOAc}}$ returned promising $\mathrm{MBC}$ values of 512 and $1024 \mu \mathrm{g} / \mathrm{mL}$ against $S$. aureus and E. faecalis, respectively. $\mathrm{E}_{\mathrm{H} 2 \mathrm{O}}$ showed minor antimicrobial bioactivity against the Gram-negative bacterium E. coli, with a MIC of $8192 \mu \mathrm{g} / \mathrm{mL}$. No bioactivity was detected against $P$. aeruginosa. 


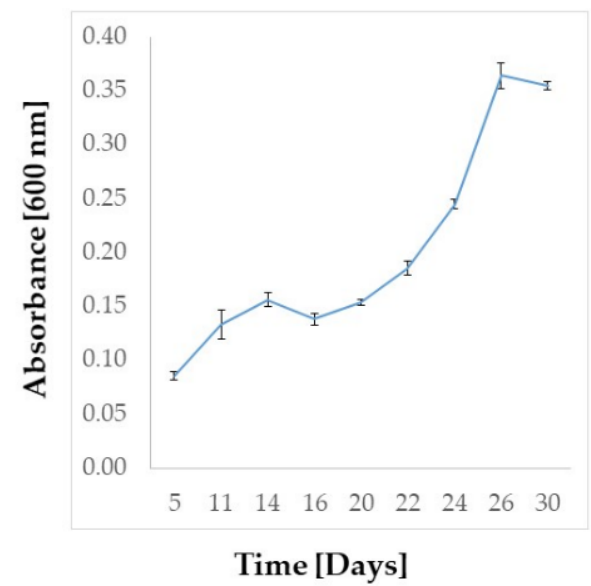

Figure 2. Batch growth of Amphidinium carterae LACW11 in $\mathrm{f} / 2$ medium monitored at $\lambda=600 \mathrm{~nm}$.

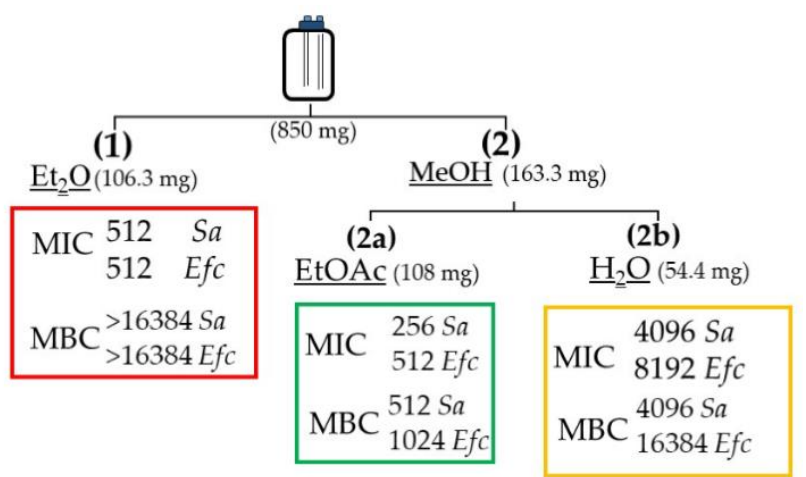

Figure 3. Representative scheme of Stage-1: three extracts obtained from Amphidinium carterae LACW11 biomass (freeze dried, mg) were screened against Gram-positive bacteria. Activities are expressed in $\mu \mathrm{g} / \mathrm{mL}$. Sa, Staphylococcus aureus ATCC 25,293; Efc, Enterococcus faecalis ATCC 29,212. The bioactivities of each extract are highlighted with different colours.

\subsection{Stage-2: Bioactivity Assays on the Fractions}

\subsubsection{Microbial Assays}

Stage-2 focused on the most bioactive extract $\mathrm{E}_{\mathrm{EtOAc}}$, which was further fractionated via $\mathrm{C} 18$ solid phase extraction into 16 fractions using mixtures of solvents of decreasing polarities $\left(\mathrm{H}_{2} \mathrm{O}: \mathrm{MeOH}: \mathrm{EtOAc}\right)$. The resulting fractions were tested against the two Gram positive bacteria (Figure 4).

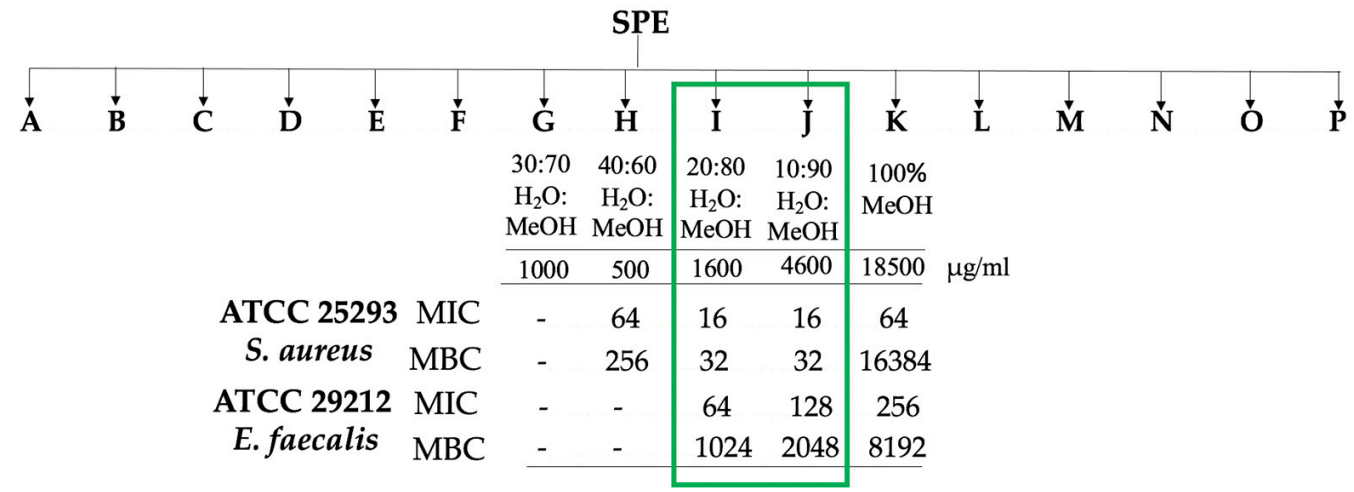

Figure 4. Representative scheme of Stage-2: fractions obtained via C18 Solid Phase Extraction (SPE) of the $\mathrm{E}_{\mathrm{EtOAc}}$ from Amphidinium carterae LACW11, which were tested against Gram-positive bacteria. Activities are expressed in $\mu \mathrm{g} / \mathrm{mL}$. The bioactivities of fractions I and J are highlighted. 
The four fractions $\mathrm{H}, \mathrm{I}, \mathrm{J}$ and $\mathrm{K}$, demonstrated some anti-bacterial activity against S. aureus and E. faecalis (MICs from 16 to $256 \mu \mathrm{g} / \mathrm{mL}$ ). Fractions I and J showed good bactericidal activity against $S$. aureus with MBC value of $32 \mu \mathrm{g} / \mathrm{mL}$. In comparison, E. faecalis showed lower susceptibility to fractions I and J, which were still bacteriostatic, returning higher MIC and MBC values than those obtained for S. aureus.

\subsubsection{Chemical Profiling of the Bioactive Fractions}

Fractions $\mathrm{G}$ to $\mathrm{K}$ were first analysed by HPLC-DAD-ELSD, evidencing major compounds by ELSD with UV profiles at maximum wavelength $210 \mathrm{~nm}$ (Figures S1-S6). Due to the low amount of material available, a purification process could not be envisioned, and we used previously described $\mathrm{m} / \mathrm{z}$ data and MS/MS fragmentation patterns in this family to assess the chemical composition of these five fractions. The UV profiles were then used as comparative data in UHPLC-DAD-HRMS/MS to obtain the MS spectra of these major compounds. Amphidinol type compounds were detected as major compounds in the bioactive fractions $\mathrm{G}-\mathrm{J}$ due to characteristic $\mathrm{m} / \mathrm{z}$ and fragmentation patterns, but these compounds were absent in fraction $\mathrm{K}$ [29]. The retention times for the compounds of interest ranged from 3.4-4.1 min with $\mathrm{m} / \mathrm{z}$ at $1667,1361,1463$ and 1343 during a $16 \mathrm{~min}$ UHPLC run (Table 1). The main fragments observed in the MS/MS fragmentation spectra of the compounds at $\mathrm{m} / \mathrm{z} 1343,1361$ and $1463[\mathrm{M}+\mathrm{Na}]^{+}$were found at $\mathrm{m} / z 1085$ and 687, while the main fragments of amphidinols/luteophanols were shown to be at $\mathrm{m} / \mathrm{z} 903$ or 1105 following the numbering recently proposed by Wellkamp et al. [29]. The only known derivatives with fragments at $m / z 1085$ (C-29/C-30) and 687 (C-29/C-30 and C-1/C-1') were identified as amphidinol A $(\mathrm{m} / \mathrm{z} 1361)$ and $\mathbf{B}(\mathrm{m} / \mathrm{z}$ 1463) from the comprehensive analysis of Wellkamp et al. [29] and Cutigano et al. [28]. A comparison between the fragmentation patterns of these compounds confirmed their identity. A third derivative at $m / z 1668[\mathrm{M}+\mathrm{Na}]^{+}$could be assigned to amphidinol-22, the only derivative with this molecular mass. The fragmentation pattern was also very similar to this known compound according to Martinez et al. [25].

Table 1. Amphidinol derivatives present in fractions G-J.

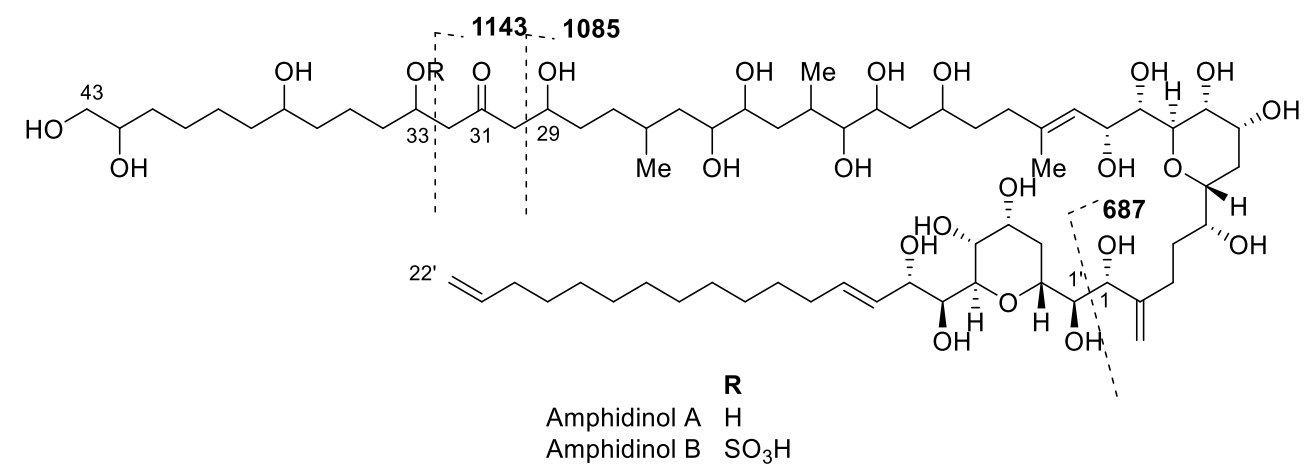

\begin{tabular}{cccccc}
\hline Compound & Fraction & $\boldsymbol{m} / \boldsymbol{z}$ Observed & $\begin{array}{c}\text { Elemental } \\
\text { Composition }\end{array}$ & RT (min) & \pm ppm \\
\hline $\mathrm{AM}-\mathrm{B}$ & $\mathrm{G}, \mathrm{H}$ & 1463.7927 & $\mathrm{C}_{69} \mathrm{H}_{125} \mathrm{Na}_{2} \mathrm{O}_{27} \mathrm{~S}$ & 4.125 & 0.192 \\
$\mathrm{AM}-22$ & $\mathrm{I}$ & 1667.9270 & $\mathrm{C}_{84} \mathrm{H}_{140} \mathrm{NaO}_{31}$ & 3.473 & 0.705 \\
AM-A & $\mathrm{I}, \mathrm{J}$ & 1361.8547 & $\mathrm{C}_{69} \mathrm{H}_{126} \mathrm{NaO}_{24}$ & 3.649 & 1.395 \\
Dehydro-AM-A & $\mathrm{J}$ & 1343.8447 & $\mathrm{C}_{71} \mathrm{H}_{122} \mathrm{O}_{23}$ & 3.766 & 1.015 \\
\hline
\end{tabular}

The collision induced MS/MS dissociation spectra obtained from fractions $G, H$, $\mathrm{I}$ and J evidenced the presence of some previously reported amphidinols [29]. Three already known compounds, AM-A, AM-B and AM-22, were found in fractions G, H and I. Another major derivative with $\mathrm{m} / \mathrm{z} 1343.8447$ was found in fraction J. The fragmentation pattern of this compound was very similar to an unknown derivative, named N16, in Wellkamp et al. [29] with a main fragment at $m / z 1085$ and no other fragment at about 1100 . 
The mass of this compound indicated that it could correspond to a dehydro derivative of AM-A. The characteristic fragmentation pattern of AM-A leads to two major fragments at $m / z 1143$ (C-32/C-33 fragmentation) and 1085 that follow a McLafferty rearrangement around the ketone at $\mathrm{C}-31$. The change in fragmentation pattern between the new derivative dehydroAM-A (N16) and AM-A with an absence of the fragment at $m / z 1143$ suggests that the dehydration might occur at position C-33, but NMR data are needed to confirm this assumption.

A comparative study was then performed on the different collected fractions targeting only the main amphidinol derivatives. A relative integration of the amphidinol derivatives was measured in the different fractions, considering the similar ionization potential between these analogues (Table 2). AM-B appeared as the major amphidinol in fractions G and $\mathrm{H}$. AM-A was found as the major amphidinol derivative in fraction I and dehydroAMA in fraction J. As both fractions are the most active on S. aureus, we can conclude that both compounds are active on this strain. Even though fraction $\mathrm{K}$ was found to be active on the two Gram-positive strains, we could not detect any amphidinol derivative. This activity should therefore originate from other metabolites to be further investigated.

Table 2. Relative proportions of the main amphidinol derivatives identified in fraction G-K. MIC values are expressed in $\mu \mathrm{g} / \mathrm{mL}$.

\begin{tabular}{cccccc}
\hline & \multicolumn{5}{c}{ Stage-2 Fractions } \\
\cline { 2 - 6 } & G & H & I & J & K \\
\hline MIC S. aureus & - & 64 & 16 & 16 & 64 \\
MIC E. faecalis & - & - & 64 & 128 & 256 \\
\hline AM-B & 100 & 100 & 0 & 0 & 0 \\
AM-22 & 0 & 0 & 8 & 0 & 0 \\
AM-A & 0 & 0 & 92 & 8 & 0 \\
DehydroAM-A & 0 & 0 & 0 & 92 & 0 \\
\hline
\end{tabular}

\section{Discussion}

There has been a pressing demand worldwide for the identification of new bioactive compounds to address the emerging issue of antibiotic resistance, which is associated with an increasing number of bacterial pathogens in both veterinary and human health settings $[4,30,31]$. The bioprospecting and screening of extracts obtained from natural sources, including marine organisms such as bacteria, microalgae, sponges, or molluscs, have led to the identification of pharmacologically active compounds with the potential for translation into novel drugs $[5,13,21,24,25]$. In particular, recent studies have reported the identification of various new bioactive from marine microbial sources $[5,13,32]$.

Microalgae constitute a polyphyletic and heterogeneous group of protists that have been portrayed as promising bioresources to further exploit owing to the scalability of their cultivation and the range of bioactive molecules they are known to biosynthesise $[9,33]$. The marine dinoflagellate genus Amphidinium has been of interest for the production of several bioactive compounds [34-36].

Amphidinium species such as A. carterae, A. massartii, A. klebsii and A. operculatum also produce molecules with antimicrobial potential, such as polyhydroxylated polyketides, which encompass an array of chemically related compounds such as amphidinols, amphidinolactones, lasonolide, iriomoteolides, amphirions, colopsinols, amphezonol, luteophanols or karatungiols [5,21-25,37-42]. There is a degree of genetic diversity among $A$. carterae isolates that has been previously revealed via the analysis of the LSU rRNA gene, leading to the delineation of four subgroups based on the clustering of specific strains within defined clades in phylogenetic inferences [32,43]. Our strain, A. carterae strain LACW11 from the west of Ireland, grouped with other strains of subclade III, including strain DN241EHU previously analysed by Wellkamp et al. [29]. These strains seem to be the only isolates originating from the northwest European Atlantic area so far. Other species complexes 
have previously been identified in marine dinoflagellates, such as the Harmful Algal Bloom (HAB) species Alexandrium tamarense, and sub-groups tend to show distinct biogeographic patterns in their global distributions [44]. There are far less sequences of Amphidinium available in GenBank compared to HAB species, but the isolates of $A$. carterae that cluster together with strain LACW11 within subclade-III appear to be globally distributed. In the context of potential inter-strain variability in the bioactivity of extracts of distinct isolates of this species, and of their chemical make-up, akin to the existing variability of toxin profiles among some HAB species [45,46], questions do arise with regard to their composition in amphidinols, which could potentially be used as chemical markers for the four previously identified subclades.

Amphidinols were first described by Satake et al. [26] from purified extracts of the species Amphidinium klebsii. While recent studies have focused on the profiling of a different family of polyketide macrolides named amphidinolides, also produced in certain strains of Amphidinium and exhibiting high cytotoxicity, there are fewer reports on the polyhydroxylated polyketides of the amphidinol family, especially on their antimicrobial potential. Of significance, Morales-Amador et al. [47] were able to purify AMs 20B, 24, 25, 26 and luteophanol D from the medium of a batch-culture of the strain A. carterae ACRN03, isolated from the Indian Ocean in La Reunion Island. Martinez et al. [25] on the other hand worked with the strain of American origin, CCMP1314, and confirmed the presence of AMs 18,19 and 22. The latter was purified, and subsequent bioactivity tests showed that these compounds do not exhibit antibacterial activity against MRSA, an MSSA strain of S. aureus. In our work, the collision induced dissociation spectra (MS/MS) obtained from fractions G-J from A. carterae LACW11 evidenced the presence of previously identified and reported amphidinols AM-A, AM-B and AM-22. Using a comparison of fragmentation patterns with known amphidinols, we suggest that a dehydroAM-A derivative, also characterized as N16 by Wellkamp et al. [29], would be the major component of fraction J. Fractions I and $J$ exhibited the highest antibacterial activity against $S$. aureus and E. faecalis. As shown by the ELSD profiles, the major amphidinols present in our strain were AM-A (Fraction I) and DehydroAM-A (Fraction J). Interestingly, this amphidinol profile shows a very high level of similarity with that of strain DN241EHU collected in Mallorca (Spain) in the Mediterranean Sea, as reported by Wellkamp et al. [29]. This strain is the only one containing the dehydro derivative N16 of amphidinol A and therefore the Irish strain represents the second example of a strain producing this derivative. The combination of chemical profiles and the bioactivities of the fractions leads to the conclusion that AM-A and its new dehydro derivative could be responsible for the antibacterial activity detected in the extracts. These results also confirm that AM-22 does not exhibit a significant antibacterial activity on the tested strains, but also that non-amphidinol derivatives should be responsible for antibacterial activity in fraction $\mathrm{K}$.

Previous studies reported the isolation and structure elucidation of metabolites from Amphidinium sp. with bactericidal, fungicidal, anti-cancer and hemolytic bioactivities $[21,24,25,48]$. Here, the initial $\mathrm{E}_{\mathrm{EtOAc}}$ extract of $A$. carterae LACW11 showed promising bioactivity against Gram-positive bacteria, in particular S. aureus. Then, the two fractions I and J resulting from the SPE-based purification process, showed inhibitory and bactericidal activities against $S$. aureus at $16 \mu \mathrm{g} / \mathrm{mL}$ and $32 \mu \mathrm{g} / \mathrm{mL}$, respectively. Kubota et al. [49] reported similar MICs, albeit using purified compounds, for Amphidinins C-F and Amphidinolide Q extracted from Amphidinium sp. (2012-7-4A strain) against Escherichia coli, Staphylococcus aureus, Bacillus subtilis, Aspergillus niger, Trichophyton mentagrophytes and Candida albicans. Other polyketide derivatives extracted from Amphidinium species, such as karatungiols or amphirionin-2, have also shown bioactivity against fungi and human cancer cell lines [41,50]. Interestingly, amphidinol-3 showed a mechanism of action similar to that of other polyene antibiotics such as amphotericin B and filipin [27]. It has been indicated that amphidinols may interact with membranes, leading to their permeabilization via pore formation and subsequent cell death [51,52]. It is noteworthy to mention that our amphidinol-containing extracts showed much greater activity against $S$. aureus 
and E. faecalis compared to E. coli and P. aeruginosa, which may reflect the fundamental differences in cell membrane and peptidoglycan characteristics between Gram-positive and Gram-negative bacteria. Antimicrobial activity against $E$. faecalis was also observed in the present study, with MIC and MBC values ranging from 64 to $256 \mu \mathrm{g} / \mathrm{mL}$ and 1024 to $8192 \mu \mathrm{g} / \mathrm{mL}$, respectively, showing bacteriostatic activity similar to that of some macrolides (e.g., erythromycin), which can become bactericidal at higher doses [53,54]. It is noteworthy that some bioactivity against $E$. faecalis was recorded for fraction $\mathrm{K}$, in which no amphidinol was detected. Moreover, fractions $\mathrm{G}$ and $\mathrm{H}$, which both contained amphidinol-B, returned very moderate antibacterial activities. These results indicate the presence of other bioactives in these fractions, and/or potential synergistic effects with other compounds. Future work will focus on purifying the new dehydroAM-A detected in our strain and on characterizing both its structure and antibacterial activity. Subjecting the microalgal cells to varying incubation regimes may also lead to the potential observation of variations in the profile of the amphidinols this species can synthesize.

\section{Materials and Methods}

\subsection{Amphidinium carterae Cultivation}

A batch culture of Amphidinium carterae LACW11 isolated from the northwest of Ireland was prepared in a sterile $10 \mathrm{~L}$ glass bottle $(6.1 \mathrm{~L}$ final volume culture) fitted with a 2-port vented cap at a starting concentration of $0.5 \mathrm{mg} / \mathrm{mL}$ (wet biomass) in $\mathrm{f} / 2$ medium without silicate $[55,56]$. The culture was incubated for 30 days at $20 \pm 1{ }^{\circ} \mathrm{C}$ under ca. $60-80 \mu \mathrm{mol} / \mathrm{m}^{2} / \mathrm{s}$ illumination provided by LED panels (white light) and a 14:10 light:dark photoperiod. Aeration through a $0.22 \mu \mathrm{m}$ filter airline was provided at a rate of $210 \mathrm{~mL} / \mathrm{min}$. On day 30, the cells were harvested by centrifugation at $2000 \mathrm{rpm}$ for $5 \mathrm{~min}$ to collect the biomass, which was then desalted with $1 \mathrm{~mL}$ of $0.5 \mathrm{M}$ ammonium formate prior to overnight freeze-drying (Scanvac. MillRock, Kingston, NY, USA) and subsequent storage at $-20^{\circ} \mathrm{C}$.

\subsection{DNA Extraction, Partial 28SrDNA Gene PCR and Sequencing}

DNA extraction was carried out using the E.Z.N.A. ${ }^{\circledR}$ Plant DNA kit (Omega Bio-Tek, Norcross, GA, USA). PCR targeting the D1D2 domain of the 28S rRNA ribosomal gene was performed using the 1X DreamTaq ${ }^{\mathrm{TM}}$ Green PCR Master MIX (Thermo Fischer Scientifics, Baltics, Vilnius, Lithuania) using the primers D1R (forward, 5' ACCCGCTGAATTTAAGCATA $3^{\prime}$ ) and D2C (reverse, $5^{\prime}$ CCTTGGTCCGTGTTTCAAGA $3^{\prime}$ ) [57]. The thermocycling program was as follows: $94{ }^{\circ} \mathrm{C}$ for 3 min then 35 cycles consisting each of $94{ }^{\circ} \mathrm{C}$ for $1 \mathrm{~min}$ (denaturation), $52{ }^{\circ} \mathrm{C}$ for $1 \mathrm{~min}$ (annealing) and $72{ }^{\circ} \mathrm{C}$ for $3 \mathrm{~min}$ (extension). A final extension step of $72{ }^{\circ} \mathrm{C}$ for $6 \mathrm{~min}$ was included prior to gel electrophoresis that was carried out using a $1 \%$ agarose 1X TEA buffer gel stained with Gel Red and observed under UV light in a transilluminator. The amplicon was purified using the E.Z.N.A ${ }^{\circledR}$ Cycle Pure Kit (Omega BIO-TEK, Norcross, GA, USA) prior to external sequencing (MWG-Eurofins, Koln, Germany).

\subsection{Phylogenetic Inference}

The Amphidinium carterae LACW11 sequence was run through BLAST against other deposits in the NCBI database. Several Amphidinium sp. and dinoflagellate LSU rDNA sequences were imported from GenBank to generate a multiple sequence alignment using Clustal W and Mega X [58]. A phylogenetic tree was constructed using a Neighbor-Joining matrix with a Tamura-Nei model and a discrete Gamma distribution (TN93 + G) [59]. Maximum likelihood was chosen using a number of three threads on nucleotide substitution. The robustness of the tre1000 replicates.

\subsection{Extraction and Fractionation of the Biomass}

The extraction and antimicrobial activity tests were carried out in two phases. For stage 1, $850 \mathrm{mg}$ of freeze-dried biomass was homogenised for $2 \mathrm{~min}$ with $55 \mathrm{~mL}$ of diethyl ether $\left(\mathrm{Et}_{2} \mathrm{O}\right)$, then incubated at $4{ }^{\circ} \mathrm{C}$ for $24 \mathrm{~h}$. The extract was centrifuged at $2000 \mathrm{rpm}$ 
for 3 min and dried using a Rotavap $\left(\mathrm{E}_{\mathrm{Et} 2 \mathrm{O}}\right)$. The residual cell materials collected after centrifugation of the initial $\mathrm{Et}_{2} \mathrm{O}$ extract were further extracted in $55 \mathrm{~mL}$ of methanol $(\mathrm{MeOH})$ for $24 \mathrm{~h}$ at $4{ }^{\circ} \mathrm{C}$. Following centrifugation at $2000 \mathrm{rpm}$ for $3 \mathrm{~min}$, the corresponding extract was dried under reduced pressure. A liquid-liquid partition $(1: 1 \mathrm{v} / \mathrm{v})$ was then carried out on this residue using $2 \mathrm{~mL}$ of ethyl acetate (EtOAc) and $2 \mathrm{~mL}$ of deionised water $\left(\mathrm{H}_{2} \mathrm{O}\right)$, returning two phases which were separately collected as fractions $\mathrm{E}_{\mathrm{EtOAc}}$ and $\mathrm{E}_{\mathrm{H} 2 \mathrm{O}}$, respectively. All final three extracts were dried and weighed prior to storage at $-20^{\circ} \mathrm{C}$ and subsequent antimicrobial activity tests.

Stage 2 focused on extract $\mathrm{E}_{\mathrm{EtOAc}}$ based on the result of the first round of antimicrobial tests. $\mathrm{E}_{\mathrm{EtOAc}}(108 \mathrm{mg})$ was resuspended in EtOAc and transferred to a $50 \mathrm{~mL}$ round bottomed flask containing $600 \mathrm{mg}$ of $\mathrm{C} 18$ powder (POLYGOPREP $60-50 \mathrm{C}_{18}$ ). The suspension was dried under reduced pressure. $\mathrm{A} \mathrm{C}_{18}$ SPE Cartridge (Agilent Bond Elut Mega BE-C18 $1 \mathrm{~g} 6 \mathrm{~mL})$ was conditioned with $\mathrm{MeOH}(2 \times 6 \mathrm{~mL})$ followed by $\mathrm{H}_{2} \mathrm{O}$ $(2 \times 6 \mathrm{~mL})$. Once conditioned, the dried sample was loaded to the column. In total, 16 fractions (12 mL each) were recovered by eluting solvents of decreasing polarity: (A) 100\% $\mathrm{H}_{2} \mathrm{O}$, (B) $\mathrm{H}_{2} \mathrm{O}: \mathrm{MeOH}(90: 10 v / v),(C) \mathrm{H}_{2} \mathrm{O}: \mathrm{MeOH}(80: 20 v / v)$, (D) $\mathrm{H}_{2} \mathrm{O}: \mathrm{MeOH}(70: 30 v / v)$, (E) $\mathrm{H}_{2} \mathrm{O}: \mathrm{MeOH}(60: 40 v / v),(\mathrm{F}) \mathrm{H}_{2} \mathrm{O}: \mathrm{MeOH}(50: 50 v / v),(\mathrm{G}) \mathrm{H}_{2} \mathrm{O}: \mathrm{MeOH}(40: 60 v / v),(\mathrm{H})$ $\mathrm{H}_{2} \mathrm{O}: \mathrm{MeOH}(30: 70 v / v),(\mathrm{I}) \mathrm{H}_{2} \mathrm{O}: \mathrm{MeOH}(20: 80 v / v),(\mathrm{J}) \mathrm{H}_{2} \mathrm{O}: \mathrm{MeOH}(10: 90 v / v),(\mathrm{K})$ 100\% $\mathrm{MeOH},(\mathrm{L}) \mathrm{MeOH}: \mathrm{EtOAc}(80: 20 \mathrm{v} / \mathrm{v}),(\mathrm{M}) \mathrm{MeOH}:$ EtOAc $(60: 40 v / v),(\mathrm{N}) \mathrm{MeOH}: \mathrm{EtOAc}$ $(40: 60 v / v),(\mathrm{O}) \mathrm{MeOH}: \mathrm{EtOAc}(20: 80 v / v)$ and $(\mathrm{P})$ 100\% EtOAc. Samples were dried under reduced pressure and weighed prior to storage for further chemical and antibacterial activity analyses.

\subsection{Chemical Profiling of the Fractions by LC-MS}

Approximately $0.2 \mathrm{mg}$ of dried extract of the 16 fractions (A to P) was resuspended in the corresponding fraction solvent at a concentration of $1 \mathrm{mg} / \mathrm{mL}$ prior to chemical profiling.

Chemical profiling was first performed on a HPLC-DAD-ELSD (Agilent Infinity 1260 Quat. pump and UV-DAD, Agilent technologies 385-ELSD). The column used was a $4.6 \mathrm{~mm} \times 250 \mathrm{~mm}$ i.d., $5 \mu \mathrm{m}$, symmetry $\mathrm{C}_{18}$ (Waters, Wexford, Ireland). The gradient was from $30 \%$ B until $5 \mathrm{~min}, 30-90 \%$ B over $20 \mathrm{~min}$ and held for $7 \mathrm{~min}$, then returned to $30 \% \mathrm{~B}$ over $2 \mathrm{~min}$ at $1.0 \mathrm{~mL} / \mathrm{min}$, held for $1 \mathrm{~min}$, and returned to the initial conditions over $1 \mathrm{~min}$ and held for $5 \mathrm{~min}$ to equilibrate the system. UV detection was performed at $\lambda 210,254$ and $290 \mathrm{~nm}$. The injection volume was $30 \mu \mathrm{L}$ and the column and sample temperatures were set at $40^{\circ} \mathrm{C}$ and $10^{\circ} \mathrm{C}$, respectively.

Samples were then run in positive MSe (200-3000 m/z) and MS/MS modes. High resolution mass spectra data were obtained with an Agilent 6540 qTof mass spectrometer UHPLC-DAD-HRMS. MS/MS data used a cone voltage was $40 \mathrm{~V}$, collision energy was $75 \mathrm{~V}$. The cone and desolvation gas flows were set at 300 and $12 \mathrm{~L} / \mathrm{min}$, respectively, and the source temperature was $300^{\circ} \mathrm{C}$. A binary gradient elution was used, with phase A consisting of water and phase $\mathrm{B}$ of acetonitrile in water (both containing $6.7 \mathrm{mM}$ ammonium formate). The column used was a $50 \mathrm{~mm} \times 2.1 \mathrm{~mm}$ i.d., $1.7 \mu \mathrm{m}$, Acquity UPLC BEH $\mathrm{C}_{18}$ (Waters, Wexford, Ireland). The gradient was from $30-90 \%$ B over $11 \mathrm{~min}$ at $0.4 \mathrm{~mL} / \mathrm{min}$, held for $1 \mathrm{~min}$, and returned to the initial conditions over $1 \mathrm{~min}$ and held for $2 \mathrm{~min}$ to equilibrate the system. The injection volume was $5 \mu \mathrm{L}$ and the column and sample temperatures were $40^{\circ} \mathrm{C}$ and $10^{\circ} \mathrm{C}$, respectively. HRMS spectra were obtained using the LCMS conditions described by Welkamp M. et al. [29]. All fractions were analysed by UHPLC-HRMS/MS.

\subsection{Microbiological Assays \\ 4.6.1. Bacterial Strains}

Microbiological assays were carried out using the Gram-positive S. aureus ATCC 25,923 and E. faecalis ATCC 29,212, and the Gram-negative E. coli ATCC 25,922 and P. aeruginosa ATCC bacterial controls. The strains were grown on solid agar media then incubated at $37^{\circ} \mathrm{C}$ overnight prior to carrying out the bioassays. The strains were grown in selective agar 
media: Bile Aescuilin Azide (BEA) for E. faecalis, Mannitol Salt Agar (MSA) for S. aureus and MacConkey agar for both E. coli and P. aeruginosa. All media were manufactured by Oxoid (Basingstoke, UK).

\subsubsection{Determination of Minimum Inhibitory Concentrations (MIC)}

The susceptibility tests were carried out using the broth microdilution assay based on the CLSI 2020 guidelines [60]. One colony of each ATCC strain was inoculated in $5 \mathrm{~mL}$ of BHI (Brain Heart Infusion broth) for $4 \mathrm{~h}$ prior to carrying out a dilution at a final concentration of $10^{5} \mathrm{cfu} / \mathrm{mL}$ for inoculation of the wells of a 96-well plate in $0.1 \mathrm{~mL}$ of sterile Muller-Hinton broth (MHB).

For the stage 1 fractions, the dried microalgal extracts were re-suspended in $4 \%$ DMSO for fraction $\mathrm{E}_{\mathrm{H} 2 \mathrm{O}}$, and $10 \%$ acetone for fractions $\mathrm{E}_{\mathrm{Et} 2 \mathrm{O}}$ and $\mathrm{E}_{\mathrm{EtOAc}}(n=3)$.

For the stage 2 fractions, all the extracts (A to P) were re-suspended in $10 \%$ acetone. Prior to bacterial inoculation, scalar dilutions (1:2) of the extracts were performed from the 1 st to the 11th wells of a row of a 96-well plate with a final volume of $100 \mu \mathrm{L}$ of $\mathrm{MHB}$. The 12th well was used as a bacterial growth control.

The antibiotics, kanamycin and colistin, were used as positive controls for the Grampositive and negative bacterial species, respectively. Control wells of MHB and solvents were also included. Triplicate wells were used for all the samples and the plates were incubated at $37^{\circ} \mathrm{C}$ for $14-18 \mathrm{~h}$. Nitro blue-tetrazolium (NBT) $(1 \mathrm{mg} / \mathrm{mL})$ was then added to each well and incubated for 30 min to determining the MIC points, based on the ability of bacteria to reduce NBT to formazan, as previously described [61].

\subsubsection{Determination of Minimum Bactericidal Concentration (MBC)}

Wells above the MIC value were plated in Muller-Hinton agar and incubated at $37^{\circ} \mathrm{C}$ overnight. The MBC value was identified by determining the lowest concentration of antibacterial agent that kills $\geq 99.9 \%$ of the bacterial population. Antibacterial agents are usually regarded as bactericidal if the MBC value is no more than 4-fold the MIC value.

\section{Conclusions}

SPE-based fractionation of extracts from an Irish isolate of Amphidinium carterae, which grouped with strains from other geographic areas within sub-clade III, returned bioactivity against the Gram-positive bacteria $S$. aureus and E. faecalis. The activity against $S$. aureus was mostly associated with fractions I and J, where amphidinols AM-A and dehydroAM-A were prominent. Fraction K returned minor activity against E. faecalis, but did not contain known amphidinols, while fractions $G$ and $H$, which contained AM-B, also did not return noteworthy antibacterial activity. Further fraction purification and testing of individual compounds is warranted.

Supplementary Materials: The following are available online at https:/ / www.mdpi.com/article/ 10.3390/ijms222212196/s1.

Author Contributions: Conceptualization: G.T.A.F., O.P.T. and N.T.; methodology: R.P., E.M., F.C. and M.E.B.; data curation: E.M. and M.E.B.; formal analysis and investigation: F.C., E.M., O.P.T. and N.T.; writing, review and editing: R.P., G.T.A.F., F.C., E.M., M.E.B., O.P.T. and N.T. All authors have read and agreed to the published version of the manuscript.

Funding: The authors acknowledge financial support from the VES4US project funded by the European Union's Horizon 2020 research and innovation programme under grant agreement No 801338. EM has received financial support from a Cullen fellowship (Grant-Aid Agreement No. $\mathrm{CF} / 18 / 03 / 01$ of the Marine Institute and funded under the Marine Research Programme by the Irish Government.

Institutional Review Board Statement: Not applicable.

Informed Consent Statement: Not applicable.

Data Availability Statement: Not applicable. 
Conflicts of Interest: The authors declare no conflict of interest.

\section{References}

1. World Health Organization (WHO). Global Antimicrobial Resistance and Use Surveillance System (GLASS) Report 2021; WHO: Geneva, Switzerland, 2021.

2. Beceiro, A.; Tomás, M.; Bou, G. Antimicrobial Resistance and Virulence: A Successful or Deleterious Association in the Bacterial World? Clin. Microbiol. Rev. 2013, 26, 185-230. [CrossRef]

3. Landecker, H. Antibiotic Resistance and Biology of History. Body Soc. 2015, 22, 1-34. [CrossRef]

4. European Centre for Disease Prevention and Control (ECDC). Antimicrobial Resistance in the EU/EEA (EARS-Net) Annual Epidemiological Report 2019; ECDC: Solna kommun, Sweden, 2019.

5. $\quad$ Blunt, J.W.; Copp, B.R.; Keyzers, R.A.; Munro, M.H.G.; Prinsep, M.R. Marine natural products. Nat. Prod. Rep. 2015, 32, 116-211. [CrossRef] [PubMed]

6. $\quad$ Cepas, V.; López, Y.; Gabasa, Y.; Martins, C.B.; Ferreira, J.D.; Correia, M.J.; Santos, L.M.A.; Oliveira, F.; Ramos, V.; Reis, M.; et al. Inhibition of Bacterial and Fungal Biofilm Formation by 675 Extracts from Microalgae and Cyanobacteria. Antibiotics $2019,8,77$. [CrossRef]

7. Carroll, A.R.; Copp, B.R.; Davis, R.A.; Keyzers, R.A.; Prinsep, M.R. Marine Natural Products. Nat. Prod. Rep. 2021, 38, 362-413. [CrossRef] [PubMed]

8. Barbosa, F.; Pinto, E.; Kijjoa, A.; Pinto, M.; Sousa, E. Targeting antimicrobial drug resistance with marine natural products. Int. J. Antimicrob. Agents 2020, 56, 106005. [CrossRef] [PubMed]

9. Khan, M.I.; Shin, J.H.; Kim, J.D. The promising future of microalgae: Current status, challenges, and optimization of a sustainable and renewable industry for biofuels, feed, and other products. Microb. Cell Factories 2018, 17, 36. [CrossRef] [PubMed]

10. Brennan, L.; Owende, P. Biofuels from microalgae-A review of technologies for production, processing, and extractions of biofuels and co-products. Renew. Suistain. Energy Rev. 2010, 14, 557-577. [CrossRef]

11. Shannon, E.; Abu-Ghannam, N. Antibacterial Derivatives of Marine Algae: An Overview of Pharmacological Mechanisms and Applications. Mar. Drugs 2016, 14, 81. [CrossRef]

12. Sanmukh, S.; Bruno, B.; Ramakrishnan, U.; Khairnar, K.; Swaminathan, S.; Paunikar, W. Bioactive Compounds Derived from Microalgae Showing Antimicrobial Activities. J. Aquac. Res. Dev. 2014, 5, 3. [CrossRef]

13. Karpiński, T.M. Marine Macrolides with Antibacterial and/or Antifungal Activity (Review). Mar. Drugs 2019, 17, 241. [CrossRef]

14. Karpiński, T.M.; Adamczak, A. Fucoxanthin-An Antibacterial Carotenoids. Antioxidants 2019, 8, 239. [CrossRef] [PubMed]

15. Dewi, C.; Falaise, C.; Hellio, C.; Bouigougnon, N.; Mouget, J. Chapter 12-Anticancer, Antiviral, Antibacterial, and Antifungal Properties in Microalgae. Microalgae Health Dis. Prev. 2018, 12, 235-261.

16. Falaise, C.; François, C.; Travers, M.; Morga, B.; Haure, J.; Tremblay, R.; Turcotte, F.; Pasetto, P.; Gastineau, R.; Hardivillier, Y.; et al. Antimicrobial Compounds from Eukaryotic Microalgae against Human Pathogens and Diseases in Aquaculture. Mar. Drugs 2016, 14, 159. [CrossRef] [PubMed]

17. Desbois, A.P.; Mearns-Spragg, A.; Smith, V.J. A fatty acid from the diatom Phaeodactylum tricornutum is antibacterial against diverse bacteria including multi-resistant Staphylococcus aureus (MRSA). Mar. Biotechnol. 2009, 11, 45-52. [CrossRef]

18. Berstein, P.S.; Li, B.; Vachali, P.P.; Gorusupudi, A.; Shyam, R.; Henriksen, B.S.; Nolan, J.M. Lutein, Zeaxanthin, and mesoZeaxanthin: The basic and clinical science underlying carotenoid-base nutritional interventions against ocular disease. Prog. Retin. Eye Res. 2016, 50, 34-66. [CrossRef] [PubMed]

19. Venugopal, V.C.; Thakur, A.; Chennabasappa, L.K.; Mishra, G.; Singh, K.; Rathee, P.; Ranjan, A. Phycocyanin Extracted from Oscillatoria minima Shows Antimicrobial, Algicidal, and Antiradical Activities: In silico and in vitro Analysis. Antiinflamm. Antiallergy Agents Med. Chem. 2020, 19, 240-253. [CrossRef]

20. Garcia Camacho, F.; Gallardo Rodrígez, J.; Sánchez Mirón, A.; Cerón García, M.C.; Belarbi, E.H.; Chisti, Y.; Molina Grima, E. Biotechnological significance of toxic marine dinoflagellates. Biotechnol. Adv. 2007, 25, 176-194. [CrossRef]

21. Kobayashi, J.; Kubota, T. Bioactive macrolides and polyketides from marine dinoflagellates of the genus Amphidinium. J. Nat. Prod. 2007, 70, 451-460. [CrossRef]

22. Kellmann, R.; Stüken, A.; Orr, R.J.S.; Svendesen, H.M.; Jakobsen, K.S. Biosynthesis and Molecular Genetics of Polyketides in Marine Dinoflagellates. Mar. Drugs 2010, 8, 1011-1048. [CrossRef]

23. Kobayashi, J.; Shimbo, K.; Kubota, T.; Tsuda, M. Bioactive macrolides and polyketides from marine dinoflagellates. Pure Appl. Chem. 2003, 75, 337-342. [CrossRef]

24. Kubota, T.; Takahashi, A.; Tsuda, M.; Kobayashi, J. Luteophanol D, New Polyhydroxyl Metabolite from Marine Dinoflagellate Amphidinium sp. Mar. Drugs 2005, 3, 113-118. [CrossRef]

25. Martinez, K.A.; Lauritano, C.; Druka, D.; Romano, G.; Grohmann, T.; Jaspars, M.; Martín, J.; Díaz, C.; Cautain, B.; De la Cruz, M.; et al. Amphidinol 22, a New Cytotoxic and Antifungal Amphidinol from the Dinoflagellate Amphidinium carterae. Mar. Drugs 2019, 17, 385. [CrossRef] [PubMed]

26. Satake, M.; Murata, M.; Yasumoto, T.; Naoki, H. Amphidinol, a polyhydroxy-polyene antifungal agent with an unprecedented structure, from a marine dinoflagellate, Amphidinium klebsi. J. Am. Chem. Soc. 1991, 112, 9859-9861. [CrossRef]

27. Houdai, T.; Matsuoka, S.; Matsumori, N.; Murata, M. Membrane-permeabilizing activities of amphidinol 3, polyene-polyhydroxy antifungal from a marine dinoflagellate. Biochim. Biophys. Acta 2004, 1667, 91-100. [CrossRef] [PubMed] 
28. Cutignano, A.; Nuzzo, G.; Sardo, A.; Fontana, A. The Missing Piece in Biosynthesis of Amphidinols: First Evidence of Glycolate as a Starter Unit in New Polyketides from Amphidinium carterae. Mar. Drugs 2017, 15, 157. [CrossRef] [PubMed]

29. Wellkamp, M.; Garcis-Camacho, F.; Duran-Riveroll, L.M.; Tebben, J.; Tillmann, U.; Krock, B. LC-MS/MS Method Development for the Discovery and Identification of Amphidinols Produced by Amphidinium. Mar. Drugs 2020, 18, 497. [CrossRef]

30. Bradley, J.; Glasser, C.; Patino, H.; Arnold, S.R.; Arrieta, A.; Congeni, B.; Daum, R.S.; Kojaoghlanian, T.; Yoon, M.; Anastasiou, D.; et al. Daptomycin for Complicated Skin Infections: A Randomized Trial. Pediatrics 2017, 139, e20162477. [CrossRef]

31. Campanile, F.; Bongiorno, D.; Borbone, S.; Venditti, M.; Giannella, M.; Franchi, C.; Stefani, S. Characterization of a Variant of the SCCmec Element in a Bloodstream Isolate od Staphylococcus intermedius. Microb. Drug Resist. 2007, 13, 7-10. [CrossRef]

32. Murray, S.; Jørgensen, M.F.; Daugbjerg, N.; Rhodes, L. Amphidinium revisited. ii. resolving species boundaries in the Amphidinium operculatum species complex (dinophyceae), including the descriptions of Amphidinium trulla sp. nov. and Amphidinium gibbosum. comb. Nov. 1. J. Phycol. 2004, 40, 366-382. [CrossRef]

33. Desbois, A.P.; Smith, V.J. Antibacterial free fatty acids: Activities, mechanisms of action and biotechnological potential. Appl. Microbiol. Biotechnol. 2010, 85, 1629-1642. [CrossRef] [PubMed]

34. Molina-Miras, A.; López-Rosales, L.; Sánchez-Mirón, A.; Cerón-García, M.C.; Seoane-Parra, S.; García-Camacho, F.; Molina-Grima, E. Long-term culture of the marine dinoflagellate microalga Amphidinium carterae in an indoor LED-lighted raceway photobioreactor: Production of carotenoids and fatty acids. Bioresour. Technol. 2018, 265, 257-267. [CrossRef] [PubMed]

35. Fuentes-Grünewald, C.; Bayliss, C.; Fonlut, F.; Chapuli, E. Long-term dinoflagellate culture performance in a commercial photobioreactor: Amphidinium carterae case. Bioresour. Technol. 2016, 218, 533-540. [CrossRef]

36. Lim, A.S.; Jeong, H.J.; You, J.H.; Park, S.A. Semi-continuous cultivation of the mixotrophic dinoflagellate Gymnodinium smaydae, a new promising microalga for omega-3 production. Algae 2020, 35, 277-292. [CrossRef]

37. Takahashi, Y.; Kubota, T.; Kobayashi, J. Amphidinolactone B, a New 26-Membered Macrolide from Dinoflagellate Amphidinium sp. J. Antibiot. 2007, 60, 376-379. [CrossRef]

38. Song, H.Y.; Joo, J.M.; Kang, J.W.; Kim, D.; Jung, C.; Kwak, H.S.; Park, J.H.; Lee, E.; Hong, C.Y.; Jeong, S.; et al. Lasonolide A: Structural Revision and Total Synthesis. J. Org. Chem. 2003, 68, 8080-8087. [CrossRef]

39. Sakamoto, K.; Hakamata, A.; Tsuda, M.; Fuwa, H. Total Synthesis and Stereochemical Revision of Irimoteolide-2a. Angew. Chem. Int. Ed. 2018, 57, 3801-3805. [CrossRef]

40. Akakabe, M.; Kumagai, K.; Tsuda, M.; Konica, Y.; Tominaga, A.; Kaneno, D.; Fukushi, E.; Kawabata, J.; Masuda, A.; Tsuda, M. Iriomoteolides-10a and 12a, Cytotoxic Macrolides from Marine Dinoflagellate Amphidinium Species. Chem. Pharm. Bull. 2016, 64, 1019-1023. [CrossRef]

41. Washida, K.; Koyama, T.; Yamada, K.; Kita, M.; Uemure, D. Karatungiols A and B, two novel antimicrobial polyol compounds, from the symbiotic marine dinoflagellate Amphidinium sp. Tetrahedron Lett. 2006, 47, 2521-2525. [CrossRef]

42. Kohli, G.S.; John, U.; Van Dolah, F.M.; Murray, S.A. Evolutionary distinctiveness of fatty acid and polyketide synthesis in eukaryotes. ISME J. 2016, 10, 1877-1890. [CrossRef]

43. Karafas, S.; Teng, S.T.; Leaw, C.P.; Alves-de-Souza, C. An evaluation of the genus Amphidinium (Dinophyceae) combining evidence from morphology, phylogenetics, and toxin production, with the introduction of six novel species. Harmful Algae 2017, 68, 128-151. [CrossRef] [PubMed]

44. Lilly, E.L.; Halanych, K.M.; Anderson, D.M. Species boundaries and global biogeography of Alexandrium tamarense complex (Dinophyceae). J. Phycol. 2007, 43, 1329-1338. [CrossRef]

45. Touzet, N.; Franco, J.M.; Raine, R. Characterization of Nontoxic and Toxin-Producin Strains of Alexandrium minutum (Dinophyceae) in Irish Coastal Waters. Appl. Environ. Microbiol. 2007, 73, 3333-3342. [CrossRef] [PubMed]

46. Tillmann, U.; Wietkamp, S.; Gu, H.; Krock, B.; Salas, R.; Clarke, D. Multiple New Strains of Amphidomataceae (Dinophyceae) from the North Atlantic Revealed a High Toxin Profile Variability of Azadinium spinosum and a New Non-Toxigenic Az. Cf. spinosum. Microorganisms 2021, 9, 134. [CrossRef] [PubMed]

47. Morales-Amador, A.; Molina-Miras, A.; López-Rosales, L.; Sánchez-Mirón, A.; García-Camacho, F.; Souto, M.L.; Fernández, J.J. Isolation and Structural Elucidation of New Amphidinol Analogues from Amphidinium carterae Cultivated in a Pilot-Scale Photobioreactor. Mar. Drugs 2021, 19, 432. [CrossRef]

48. Tsuda, M.; Endo, T.; Kobayashi, J. Amphidinolide T, Novel 19-Membered Macrolide from Marine Dinoflagellate Amphidinium sp. J. Org. Chem. 2000, 65, 1349-1352. [CrossRef] [PubMed]

49. Kubota, T.; Iwai, T.; Sakai, K.; Gonoi, T.; Kobayashi, J. Amphidinins C-F, amphidinolide Q analogues from marine dinoflagellate Amphidinium sp. Org. Lett. 2014, 7, 5624-5627. [CrossRef] [PubMed]

50. Kumagai, K.; Minamida, M.; Akakabe, M.; Tsuda, M.; Konishi, Y.; Tominaga, A.; Tsuda, M.; Fukushi, E.; Kawabata, J. Amphirionin2, a novel linear polyketide with potent cytotoxic activity from a marine dinoflagellate Amphidinium species. Bioorg. Med. Chem. Lett. 2015, 25, 635-638. [CrossRef]

51. Espiritu, R.A.; Matsumori, N.; Tsuda, M.; Murata, M. Direct and Stereospecific Interaction of Amphidinol 3 with Sterol in Lipid Bilayers. Biochemistry 2014, 53, 3287-3293. [CrossRef]

52. Morsy, N.; Houdai, T.; Konoki, K.; Matsumori, N.; Osihi, T.; Murata, M. Effects of lipid constituents on membrane permeabilizing activities of amphidinols. Bioorg. Med. Chem. 2008, 16, 3084-3090. [CrossRef]

53. Patel, P.H.; Hashmi, M.F. Macrolides. In StatPearls; StatPearls Publishing: Treasure Island, FL, USA, 2021. Available online: https: / / www.ncbi.nlm.nih.gov/books/NBK551495/ (accessed on 4 November 2021). 
54. Vázquez-Laslop, N.; Mankin, A.S. How macrolide antibiotic work. Trends Biochem. Sci. 2018, 43, 668-684. [CrossRef] [PubMed]

55. Guillard, R.L.; Ryther, J.H. Studies of Marine Planktonic Diatoms: I. Cyclotella nana Hustedt, and Detonula confervacea (cleve) Gran. Can. J. Microbiol. 1962, 8, 2. [CrossRef] [PubMed]

56. Guillard, R.L. Culture of Marine Invertebrate Animals: Culture of Phytoplankton for Feeding Marine Invertebrates; Smith, W.L., Chanley, M.H., Eds.; Springer: Boston, MA, USA, 1975; pp. 29-60.

57. Lenaers, G.; Maroteaux, L.; Michot, B.; Herzog, M. Dinoflagellates in evolution. A molecular phylogenetic analysis of large subunit ribosomal RNA. J. Mol. Evol. 1989, 1, 40-51. [CrossRef]

58. Kumar, S.; Stecher, G.; Li, M.; Knyaz, C.; Tamura, K. MEGA X: Molecular Evolutionary Genetics Analysis across computing platforms. Mol. Biol. Evol. 2018, 35, 1547-1549. [CrossRef]

59. Tamura, K.; Nei, M. Estimation of the number of nucleotide substitutions in the control region of mitochondrial DNA in humans and chimpanzees. Mol. Biol. Evol. 1993, 10, 512-526. [PubMed]

60. Clinical Laboratory Standard Institute (CLSI). Performance Standards for Antimicrobial Susceptibility Testing; CLSI guideline M100; Clinical and Laboratory Standards Institute: Wayne, PA, USA, 2020.

61. Urban, T.; Jarstrand, C. Rapid determination of the susceptibility of bacteria to antibiotics with "Sensititre" plates and nitroblue tetrazolium. J. Antimicrob. Chemother. 1981, 8, 363-369. [CrossRef] 